\title{
66 HIGH PRECISION LEVELING SURVEY FOLLOWING THE MD 4.0 CASAMICCIOLA EARTHQUAKE OF AUGUST 21, 2017 (ISCHIA, SOUTHERN ITALY): FIELD DATA AND PRELIMINAR INTERPRETATION,
}

\author{
Ciro Ricco ${ }^{1}$, Giuliana Alessio ${ }^{1}$, lda Aquino ${ }^{*},{ }^{1}$, Giuseppe Brandi ${ }^{1}$, Carlo Alberto Brunori ${ }^{2}$, \\ Vincenzo D’Errico ${ }^{1}$, Mario Dolce ${ }^{1}$, Giuliana Mele ${ }^{2}$, Rosa Nappi ${ }^{1}$, Luca Pizzimenti ${ }^{2}$, \\ Vincenzo Sepe ${ }^{3}$, Valeria Siniscalchi ${ }^{1}$ and Carlo Del Gaudio ${ }^{1}$ \\ (1) Istituto Nazionale di Geofisica e Vulcanologia, Osservatorio Vesuviano, Napoli, Italy \\ (2) Istituto Nazionale di Geofisica e Vulcanologia, Sezione Roma1, Roma, Italy \\ (3) Istituto Nazionale di Geofisica e Vulcanologia, Osservatorio Nazionale Terremoti, Roma, Italy
}

Article history

Receveid May 23, 2018; accepted December 10, 2018.

Subject classification:

High precision leveling; Volcano monitoring; Vertical deformations; Coseismic deformation.

\begin{abstract}
The aim of this paper is the presentation of the results obtained from the high precision leveling survey carried out from November 6 to 11, 2017, in the area hit by the Md 4.0 Casamicciola earthquake of August 21, 2017, and critical discussion of these results in the light of the possible seismic source models. The measurements have been carried out on benchmarks of the northwestern sector of the altimetric network of the Ischia island, in the epicentral area. The heights of each benchmark have been obtained considering the historical reference benchmark n.1 located at Ischia Porto, and have been compensated over the whole stretch of the measured network; such heights have also been compared with those derived from the previous leveling campaign that was performed along the entire network in June 2010. The results obtained from the specific investigated leveling lines, which are considered representative of the kinematics of the northwestern area of the island, show conspicuous anomalies of ground deformation in the epicentral area of the August 21, 2017 earthquake. In particular, a significant ground subsidence of about 3.5 centimeters has been found between the benchmarks n. 92 and n. $98 \mathrm{~A}$ along the "Borbonica Line", quite anomalous compared to the previous measurements. Such subsidence located between the Piazza Maio (Casamicciola) and Fango (Lacco Ameno) localities, results spatially correlated with the deformation detected by the InSAR data analysis and coincides with the greatest macroseismic damages and with the coseismic surface fracture systems E-W oriented. Future leveling campaign in the area would be very crucial in order to follow and define the rate of postseismic motion of the seismogenetic source, also contributing with independent and valuable data to the seismic hazard knowledge of the Ischia island.
\end{abstract}

\section{INTRODUCTION}

The Ischia island (southern Italy) is an active volcanic area located at the northwestern side of the Gulf of Naples. It is part of the Campi Flegrei Volcanic District (Figure 1) together with the Procida island, and was originated following the Pliocene-Quaternary extension, which generated the graben of the Campanian Plain along the Tyrrhenian margin of the Apennines belt [Ippolito et al., 1973; D’Argenio et al., 1973; Finetti and
Morelli, 1974; Bartole, 1984; Acocella and Funiciello, 1999; Piochi et al., 1999; Piochi et al., 2005; Sacchi et al, 2009; de Vita et al., 2010].

The volcanic activity started around 150 ka [Vezzoli, 1988] and was characterized by several effusive and explosive eruptions alternated with periods of quiescence [Vezzoli, 1988; Tibaldi and Vezzoli, 2000; Tibaldi and Vezzoli, 2004; Bruno et al., 2002; de Vita et al., 2010]. The most impacting event in the geological history of the island was the Green Tuff eruption (55 ka), followed 


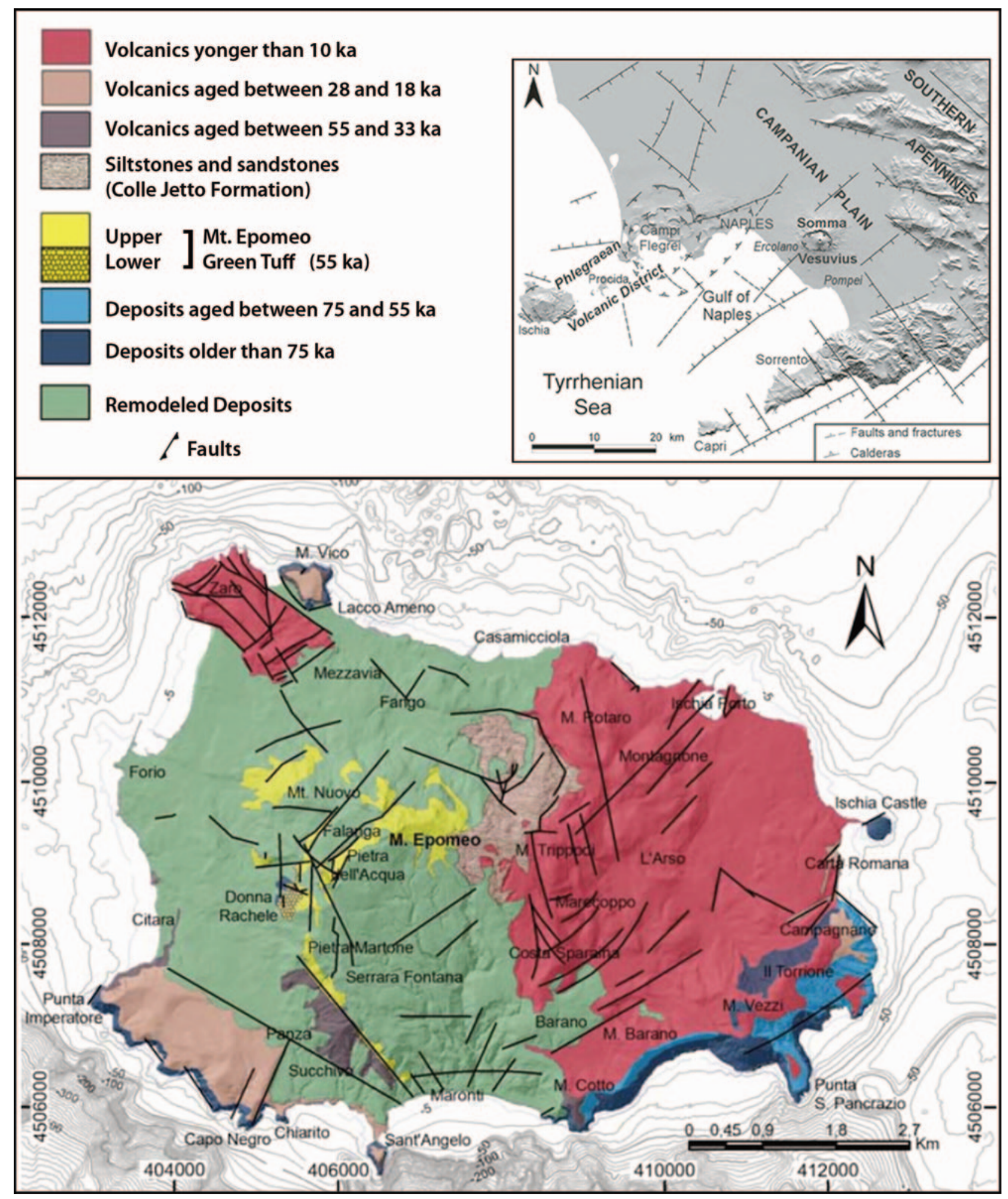

FIGURE 1. Geological and structural map of the Ischia Island [de Vita et al., 2010, modified].

by the collapse of the central sector forming a large caldera; inside it the Mt. Epomeo block resurgence started 30 ka [Gillot et al., 1982; Civetta et al., 1991; Orsi et al., 1991; Orsi et al., 1994; Orsi et al., 1999; de Vita et al., 2006]. The uplift of the resurgent Mt. Epomeo block was controlled by E-W normal fault systems, well described in the literature [Vezzoli, 1988; Orsi et al., 1991; Tibaldi and Vezzoli, 1998; Tibaldi and Vezzoli, 2004; Acocella and Funiciello, 1999; de Vita et al., 2010; Nappi et al., 2010].

The last period of volcanic activity occurred $10 \mathrm{ka}$, with eruptions located in the eastern sector of the island, 
and ended with the last effusive Arso eruption in 1302 [Chiesa et al., 1986; Iacono, 1996; de Vita et al., 2010]. (Figure 1).

Since the last eruption, the volcanic system has shown its persistent state of activity through intense hydrothermal activity [Chiodini et al., 2004], ground deformation [INGV-Osservatorio Vesuviano, 2000, 2001, 2002, 2004; INGV, 2005; Del Gaudio et al., 2011; Sepe et al., 2007; Sepe et al., 2009], slope instability and seismic activity. The hydrotermal activity, characterized by fumaroles, hot springs, and diffuse degassing areas, is concentrated along faults bounding the northern and western flanks of Mt. Epomeo. Slope instability is mainly concentrated in the northern and western sectors of the et al., 2006] and July 28, 1883 [Imax =XI MCS and $\mathrm{M}=5.2$, Cubellis and Luongo, 1998; Gruppo di Lavoro CPTI, 2004; Esposito et al., 2006].

In the island of Ischia currently there are about 60,000 inhabitants distributed in 6 municipalities, but in the summer the population increases and consequently the seismic/volcanic risk in terms of exposed value.

The dynamics of the island is constantly monitored by the Istituto Nazionale di Geofisica e Vulcanologia - Osservatorio Vesuviano (INGV-OV) surveillance system that consists of geophysical and geochemical networks (Figure 2); this system was established and is managed by the Osservatorio Vesuviano (OV). In particular, instruments for seismicity and ground deformation continuous monitor-

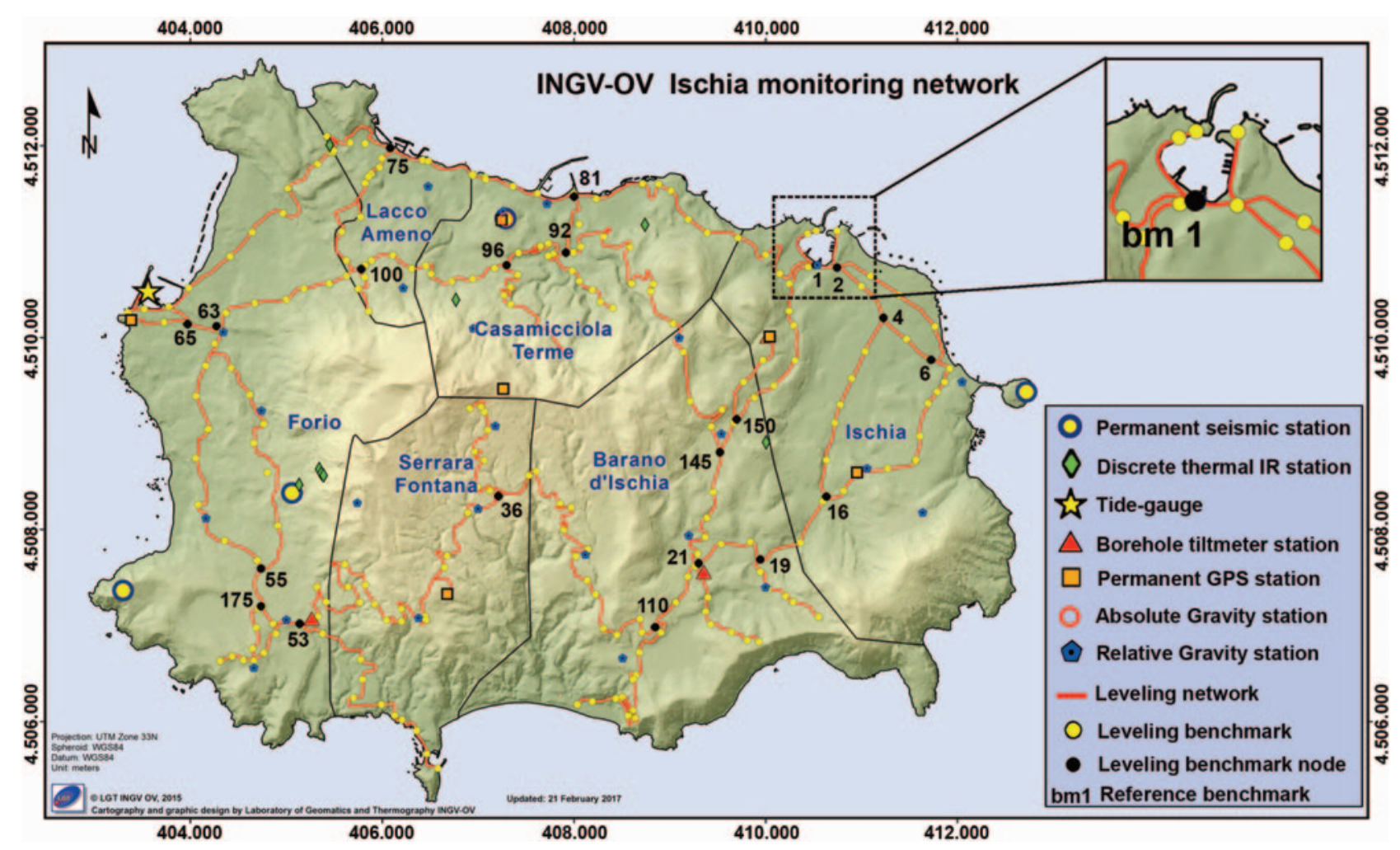

FIGURE 2. INGV-OV Ischia monitoring networks.

island and in the southern flank of Mt. Epomeo [Del Prete and Mele, 2006; Guadagno and Mele, 1995; Mele and Del Prete, 1998; Tibaldi and Vezzoli, 2004]. The Ischia island has been characterized by intense seismic activity since pre-historical and historical times mainly located in the northern sector of the island; the strongest historical earthquakes (VIII $<\mathrm{I}<\mathrm{XI}$ MCS) occurred in the eighteenth and nineteenth centuries [Cubellis and Luongo, 1998; Gruppo di Lavoro CPTI, 2004; Luongo et al., 2006], as the well known destructive earthquakes of March 4, 1881 [I=IX MCS, Alessio et al., 1996; Esposito ing are currently operating; moreover, geophysical and geochemical periodic surveys are carried out for better constraining the geodinamic activity.

The analysis and interpretation of the data acquired by continuous measurements, integrated with the data obtained by geophysical and geochemical periodic surveys, allow researchers to increase scientific knowledge aiming to monitor the island for civil protection purposes.

For what concerns geophysical surveillance, the ground deformation monitoring is detected by continuous Global Positioning System (cGPS) geodetic mea- 
surements and by Tiltmetric network continuous measurements, as well as through Interferometric Syntetic Aperture Radar (InSAR) technique and periodic geodetic surveys (absolute and relative gravimetry, high precision leveling and GPS).

In particular, high precision spirit leveling allows the space-time monitoring of the vertical component of the deformation field by means of periodic measurements of height differences between fixed points called "Benchmarks" (Bm). At the moment, this is the only independent technique that provide measurement errors less than one millimeter on the computed heights.

The high precision spirit leveling is also an useful technique for volcanoes monitoring along slopes where eruptive fractures are more likely to occur [Luongo et al., 1990; Dsurizin, 2003; Murase et al., 2016]. Relatively to the whole leveling measurements survey, the mean error per kilometer (standard deviation evaluated for the distance of $1 \mathrm{~km}$ ) multiplied by the root square of the length expressed in $\mathrm{km}$ must be less than $1 \mathrm{~mm} / \sqrt{ } \mathrm{km}$ to ensure the greatest accuracy. Geodetic measurements, obtained by precise leveling since 1978, provide a tool for documenting the rate of movement of the island through time. We organized and analyzed all information on the vertical component of the ground motion, with a detailed study of the vertical movements between 2003 and 2017 [Del Gaudio et al., 1987, 2011].

The performed analysis has provided spatial and temporal information on the volcanic island dynamics that can contribute to the investigation, modeling and interpretation of the physical processes behind the observed deformation phenomena in the Ischia island.

\section{THE ISCHIA HIGH PRECISION LEVELING SURVEY}

In areas of active tectonics the topographic leveling technique has been often performed in order to detect any ground deformation and the possible relative sources. Leveling networks are occupied repeatedly, and the difference between successive surveys represents an estimate of crustal deformation over time [Arca and Beretta, 1982; Yeats et al., 1997; D’Anastasio et al., 2006]. For this reason, this technique has been frequently applied in many volcanic and tectonic areas for the study of different geophysical phenom- ena [Luongo et al., 1990; Arnadottir et al., 1992; Amoruso et al., 1998; Obrizzo et al., 2001; Cheloni et al., 2012]. In particular, in case of earthquake occurrence, coseismic and postseismic ground deformation amounts due to earthquake source motion can be calculated, comparing the obtained measurements with previous rates of ground deformation and with previous heights of the near field benchmarks.

In 1910 the Istituto Geografico Militare (IGM) (Italian Army Geographic Institute of Italy) was instructed to perform a campaign of precision altimetric measurements, following the great flood that involved "La Sentinella" and "Piazza Bagni" localities in Casamicciola village [Loperfido, 1914]. Therefore, the first precision leveling survey was operated by IGM in 1913 along the State Road encircling the island (currently called "Coast Line", Figure 3, in blue color) and repeated in 1967 by the Italian Geodetic Society (SGI) [Osservatorio Vesuviano, 1979].

From 1978 to 2010 new leveling lines including new benchmarks were installed by the Osservatorio Vesuviano in order to improve the ground deformation monitoring. In Figure 3 the schematic map with the different leveling lines and the relative year of implementation are shown in different colours [Del Gaudio et al., 1987, 2011].

Nowadays the high precision spirit leveling of Ischia Island consists of 257 benchmarks with a mean mutual distance of 300 meters each, for a total of about 100 $\mathrm{km}$ of leveling line with ten linked loops; the relative measurements are subjected to least squares compensation with the method of indirect observations [Inghilleri, 1974].

The reference benchmark is located in the Ischia Porto zone (precisely on the wall of the S. Maria of Portosalvo church) and is marked by number $1(\mathrm{Bm} \mathrm{1)}$ in the upper right corner (Figure 2). Its stability is confirmed by the fact that it is placed at the center of an area about $3 \mathrm{~km} 2$ in which both the leveling and GPS surveys carried out in the past have measured a small amount of subsidence, thus testifying low dynamics of this area compared to ground deformation affecting other sectors of the island.

Starting from the first days of November 2017 a high precision leveling survey was carried out along the line located in the northwestern sector of the Ischia island (Figure 4), in order to check for any anomalies following the seismic event $\mathrm{Md}=4.0$ occurred on $\mathrm{Au}$ gust 21 2017, at 18:57:51 UTC, which mainly hit the lo- 


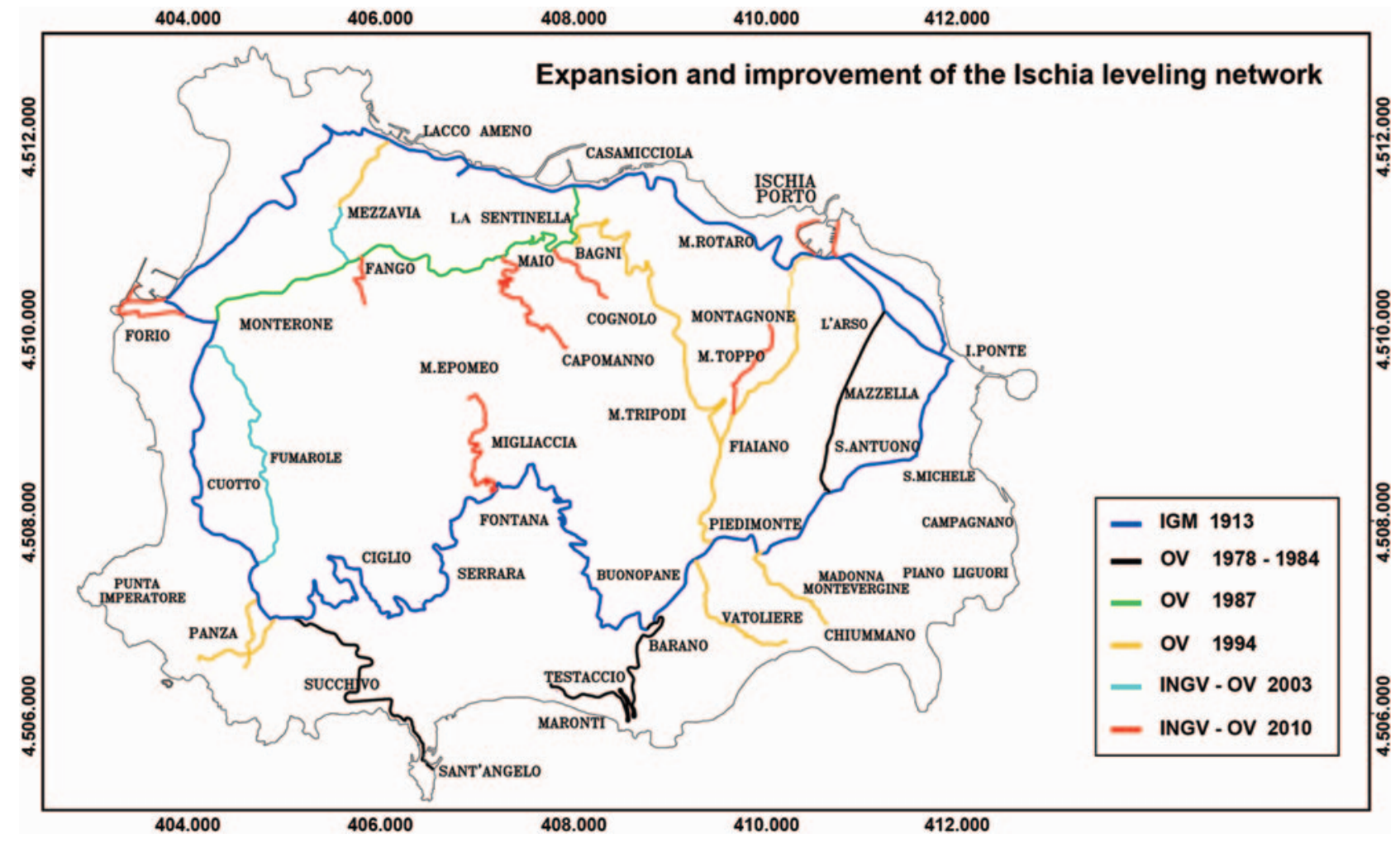

FIGURE 3. Ischia high precision leveling network; the different colors identify leveling lines or transects established in different periods as reported in the legend on the map [Del Gaudio et al., 2011].

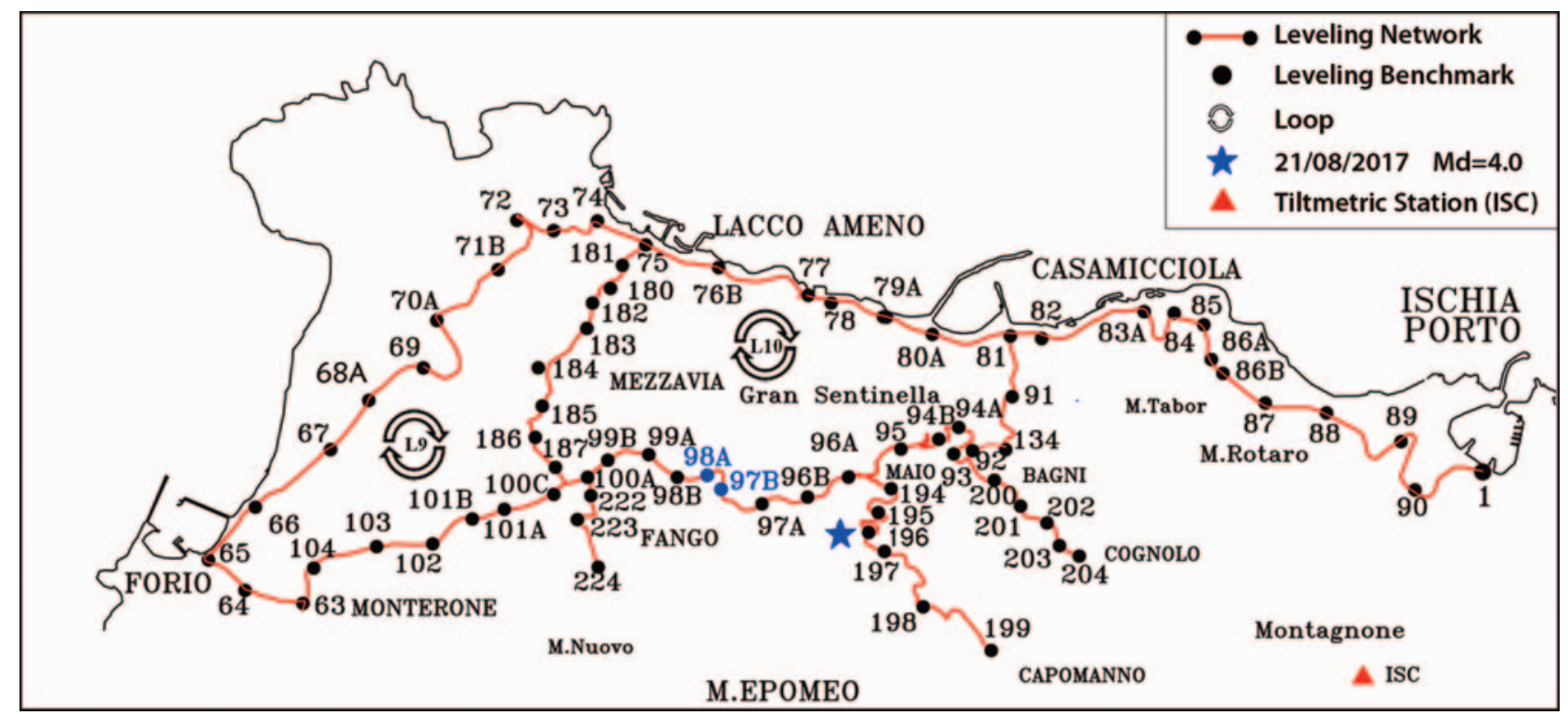

FIGURE 4. NW sector of the leveling network where measurements were carried out in November 2017.

calities of Piazza Bagni and Piazza Maio in the Casamicciola Municipality.

The measurements and the logistics of the campaign were assigned, in total, to 11 qualified personnel; two teams of 4 units were gathered and equipped with an electronic level (Leica Geosystems mod. DNA03) for measurements with precision of $0.3 \mathrm{~mm} / \mathrm{km}$ of double run leveling (differences between benchmarks measured in both directions) and two bars in aluminum with barcode on the Invar belt. In the sectors characterized by steep slopes, the electronic level was replaced with a Leica Geosystems optical self-leveling 


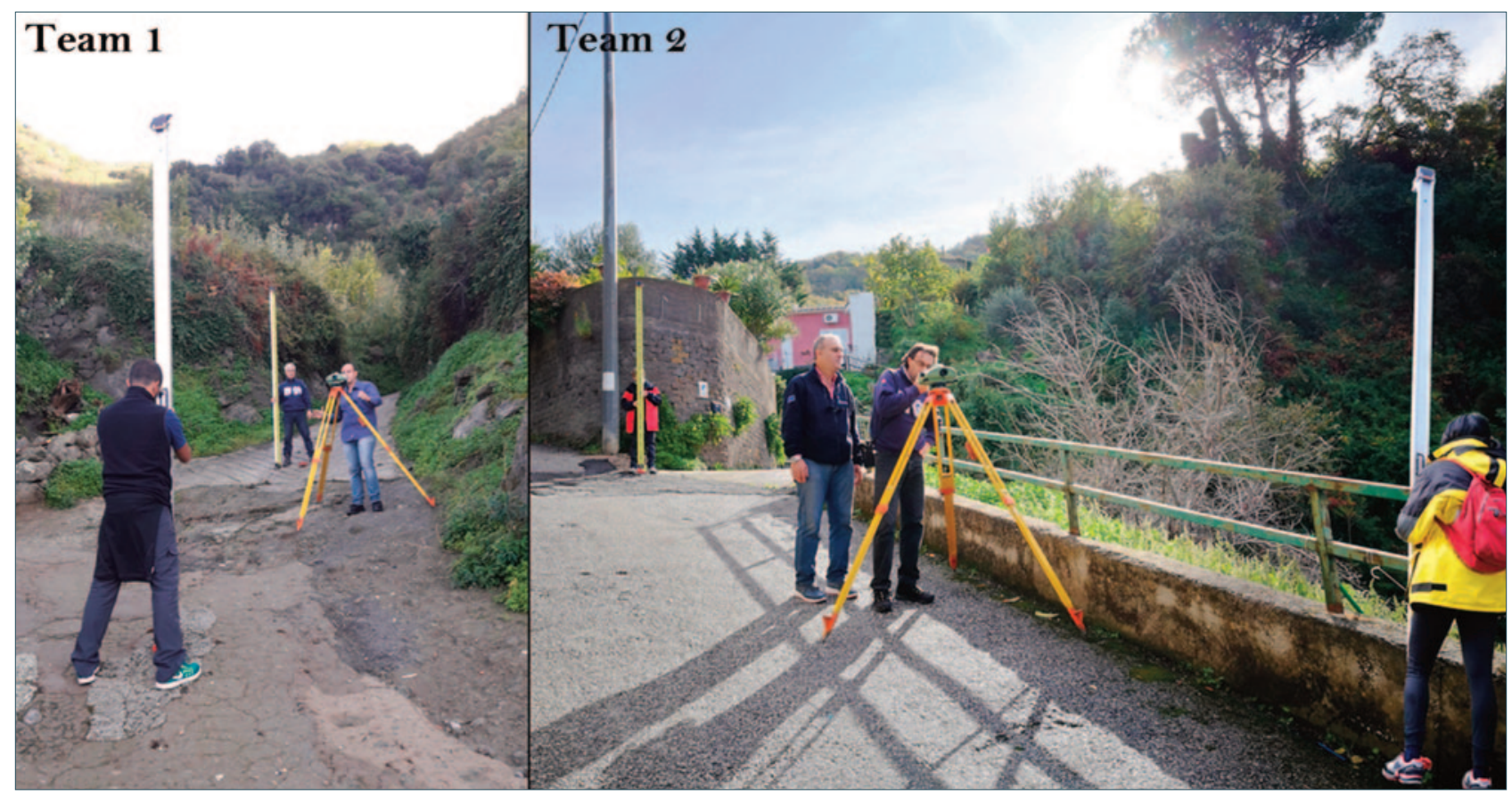

FIGURE 5. Field measurements in the leveling survey.

level mod. NA2 (Figure 5).

The survey was carried out on 72 benchmarks of the altimetric network located in the epicentral and surrounding areas, in the sector between the municipalities of Casamicciola, Lacco Ameno and Forio, covering a length of about $30 \mathrm{~km}$ (Figure 4).

The 5 leveling stretches that were surveyed are as follows:

1. the "Coast Line" from Ischia Porto (Bm 1) to Forio in Monterone (Bm 63) passing through Casamicciola and Lacco Ameno;

2. the "Borbonica Line" from Monterone (Forio) (Bm 63) to Casamicciola with closure of the circuit at Bm 81 on the "Coast Line" passing through Fango (Lacco Ameno), Maio and Bagni (Casamicciola);

3. the "Mezzavia Line" that starts from the Bm 75 of the "Coast Line" up to the Lacco Ameno Porto and connects with Fango along the North-South line (Bm 100A of the "Borbonica Line"), then continues on the spurs of the Mt. Nuovo up to Bm 224;

4. the "Maio-Capomanno Line", which starts from the Bm 96A of the "Borbonica Line" (Piazza Maio) and then continues on the spurs of the Mt. Nuovo up to the Bm 199 in Capomanno;

5. the "Bagni-Cognolo Line" that starts from the Bm 92 of the "Borbonica Line" (Piazza Bagni) and then continues on the spurs of the Mt. Nuovo up to the Bm 204 in the locality of Cognolo.
The closing errors of the two loops L9 and L10 (Table 1, Figure 4), both about $8.5 \mathrm{~km}$ long, were less than the maximum tolerance allowed TMax $= \pm 2 * \sqrt{\mathrm{L}}(\mathrm{Km})$, where $\mathrm{L}$ is the length of each loop in $\mathrm{km}$ (obtained from the readings on the rods); thus the measured differences

\begin{tabular}{ccccc} 
Loop & $\begin{array}{c}\mathrm{L} \\
(\mathrm{km})\end{array}$ & $\begin{array}{c}\text { Err } \\
(\mathbf{m m})\end{array}$ & $\begin{array}{c}\text { Err. Max } \\
(\mathbf{m m})\end{array}$ & $\begin{array}{c}\text { Err/Err } \\
\max \%\end{array}$ \\
$\begin{array}{c}\text { L9 MEZZAVIA } \\
\text { L10 LACC0 }\end{array}$ & 8.6 & 2.92 & 5.9 & 49.8 \\
AMEN0 & 8.4 & -4.46 & 5.8 & 76.9 \\
& & & & \\
\hline
\end{tabular}

TABLE 1. Errors of closure for the two loops L9 and L10.

can be considered not due to accidental causes.

The orthometric height of 72 investigated benchmarks is obtained by minimizing the misclosures of each loop by means of a least squares compensation applied to the measured elevation differences between successive benchmarks. The Bm 1, located in Ischia (Figure 2), Church of S. Maria di Portosalvo $\left(\mathrm{H}_{\text {ort }}=3.0360 \mathrm{~m}\right)$ has been set as a reference benchmark.

The standard deviation per unit of weight calculated on the compensated network was lower than the unit $\left(\sigma_{0}=0.994 \mathrm{~mm}\right)$, demonstrating the high accuracy of the performed measurements. 


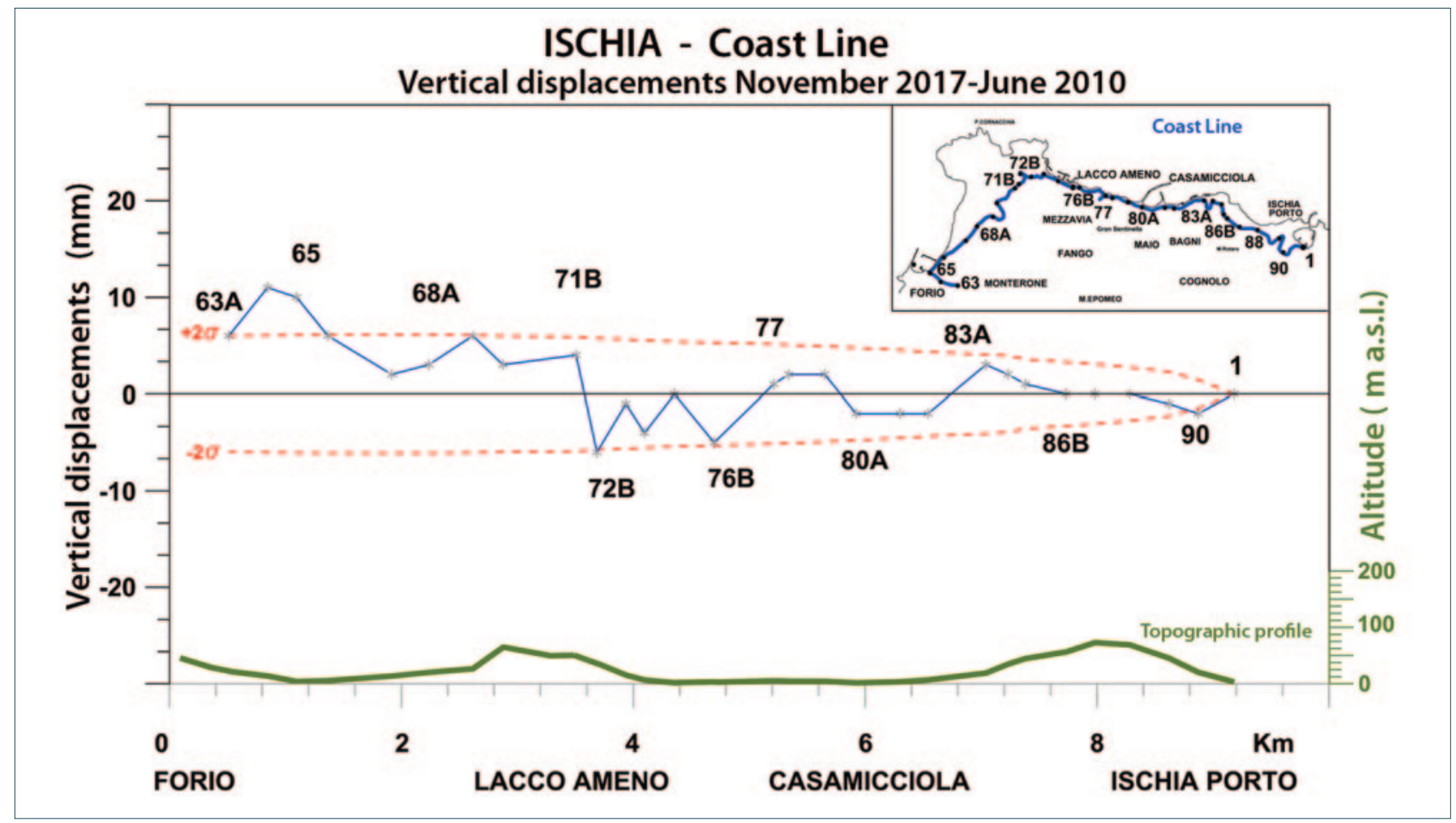

FIGURE 6. "Coast Line". Differences between the heights measured in 2017 and those of 2010. Blue line with asterisks: vertical displacements; red dotted line: confidence limits 95\%; green line: topographic profile; on the abscissae: the minimum progressive distances between benchmarks; small box: schematic map of the line location.

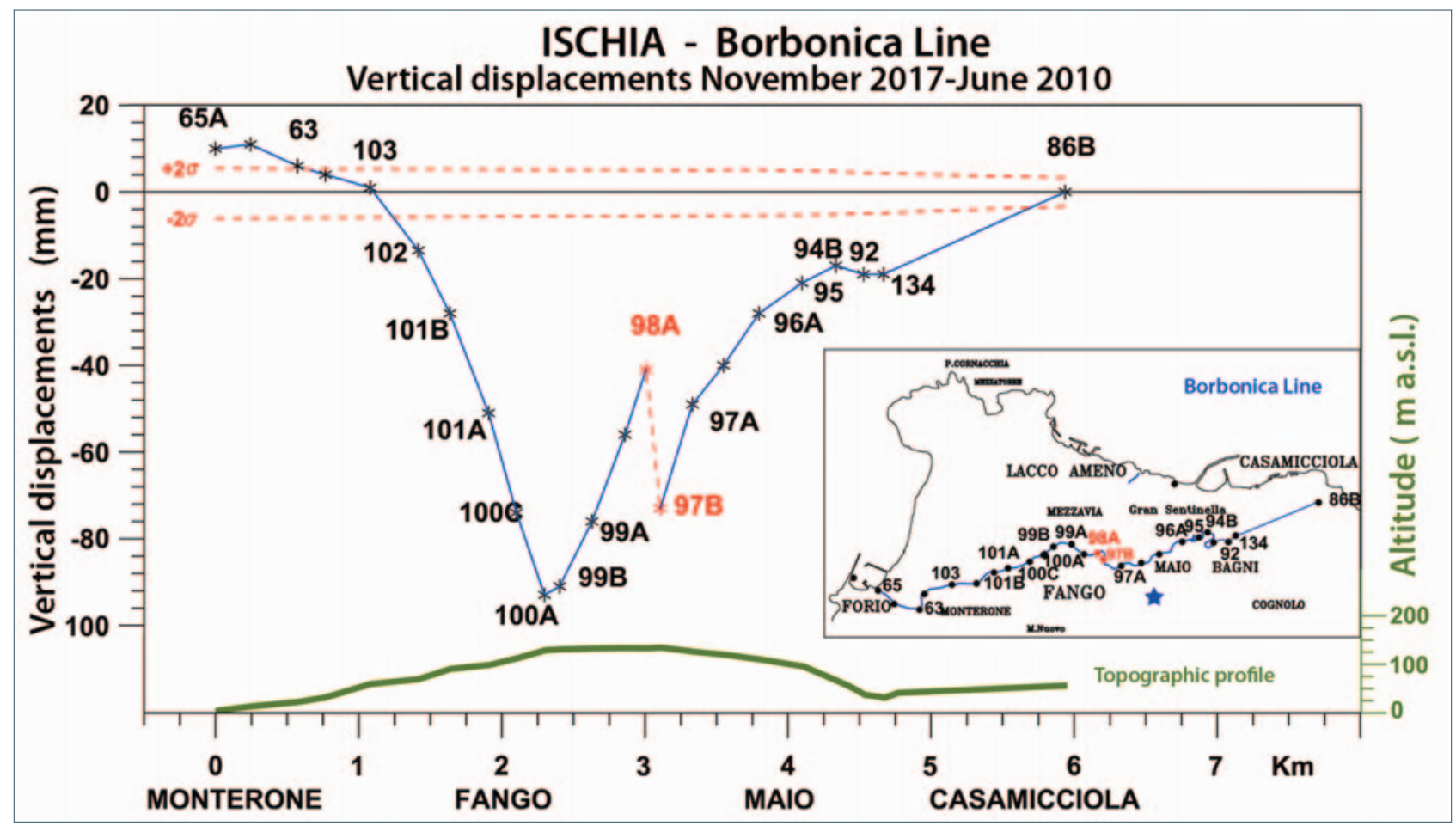

FIGURE 7. "Borbonica Line”. Differences between the heights measured in 2017and those of 2010. Blue line with asterisks: vertical displacements; red dotted line: confidence limits 95\%; green line: topographic profile; on the abscissae: the minimum progressive distances between benchmarks; small box: schematic map of the line location; blue star: 21 August earthquake. 


\section{RESULTS}

In order to provide a detailed trend of the observed vertical deformations, the results obtained through the November 2017 leveling campaign have been compared with those of June 2010 and discussed in the following. Both campaigns are referred to the same reference benchmark Bm 1.

At first, the data obtained from the five lines investigated, considered adequately representative of the kinematics of the North and North-West sector of the island, show considerable anomalies in the epicentral area of the August 2017 earthquake.

These anomalies will be highlighted in the following six figures (Figures 6 to 11):

- “Coast Line” (Figure 6). Along this line from Bm 1 to $\mathrm{Bm} 77$ there are no significant variations compared to the previous 7 years; only a slight subsidence, with almost no statistical significance, is ev- most invariant space-time trend of general subsidence [Del Gaudio et al., 2011]. In fact, the subsidence pattern is characterized by minimum values starting from Bm 86, increasing significantly, continuing towards the localities "Bagni" and "Maio" at Casamicciola (Bm 96A). Towards Lacco Ameno, the lowering of the ground is constantly increasing and reaches maximum values at $\mathrm{Bm} 100 \mathrm{~A}$ in the locality "Fango" (Lacco Ameno), then progressively decreases ending at Bm 103 in Monterone (Forio). The maximum deformation rates, calculated at $\mathrm{Bm}$ 100A from 1987 to 2010, have remained fairly constant over time with values of $-11.83 \pm 0.26$ $\mathrm{mm} /$ year [Del Gaudio et al., 2011]. The measurements performed in November 2017 (referred to June 2010) show once again that the maximum lowering is found at Bm 100A with $-93 \pm 4.0 \mathrm{~mm}$ (Figure 7). These measurements show, contrary to what happened in the past, a strong subsidence be-

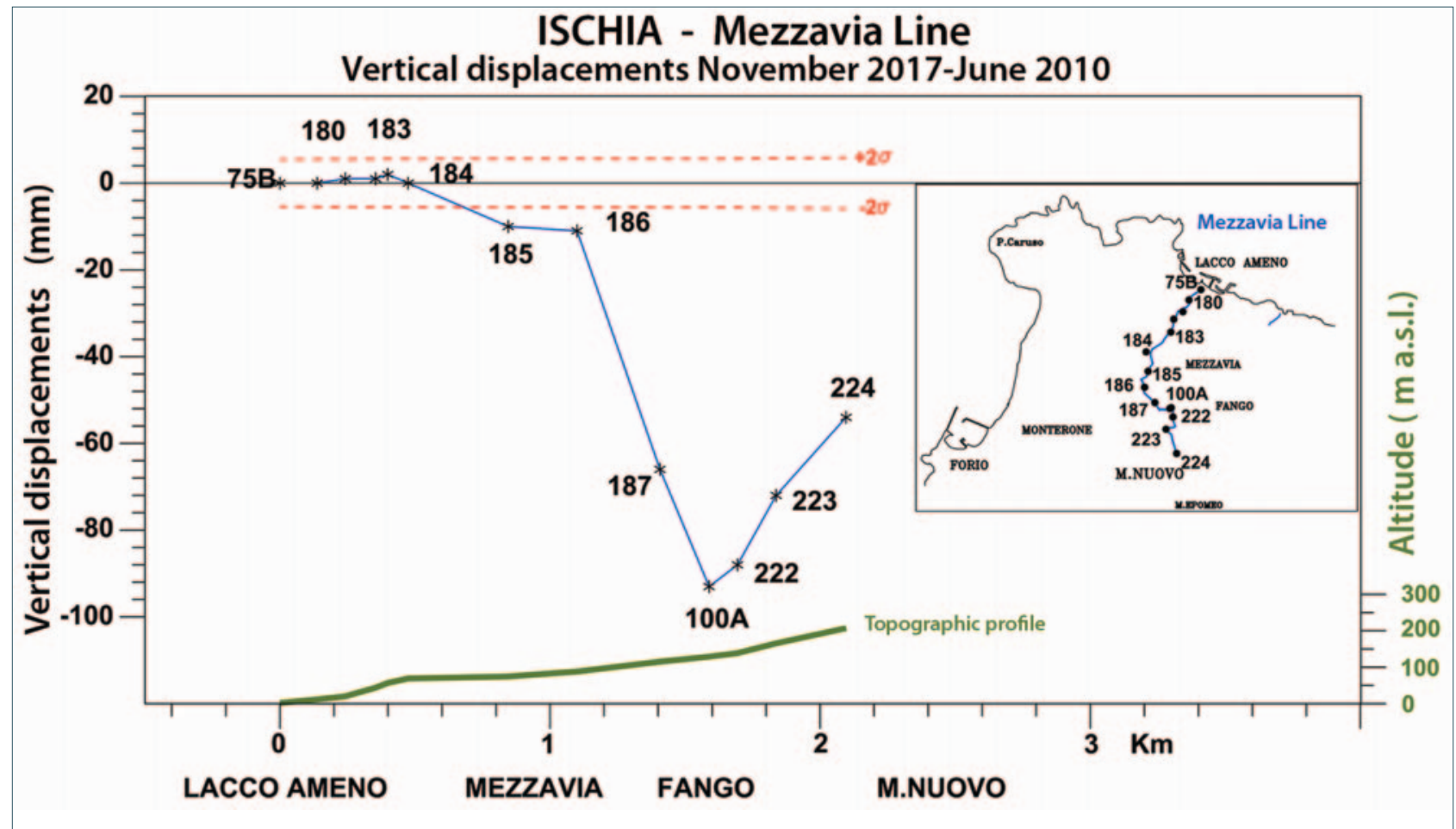

FIGURE 8. "Mezzavia Line”. Differences between the heights measured in 2017 and those of 2010. Blue line with asterisks: vertical displacements; red dotted line: confidence limits 95\%; green line: topographic profile; on the abscissae: the minimum progressive distances between benchmarks; small box: schematic map of the line location.

ident at $\mathrm{Bm} 76 \mathrm{~B}$ and $\mathrm{Bm} 72 \mathrm{~B}$ in Marina di Lacco Ameno while, from Bm 65 to Bm 64, we observe a slight but statistically significant uplift (around 10 $\mathrm{cm}$ ) in the Forio - Monterone area.

- "Borbonica Line" (Figure 7). Before discussing this figure we must anticipate that long-term deformation (starting from 1987) has always shown an al- tween the Bm 94B and 97B which, however, suddenly reverses its sign between the Bm 97B and 98A with a step of $36 \mathrm{~mm}$. This jump corresponds either to the uplift of the $\mathrm{Bm} 98 \mathrm{~A}$ respect to $\mathrm{Bm} 97 \mathrm{~B}$ or to a greater subsidence of the area located at East of 97B, where the epicenter of the 21 August earthquake has been localized. 


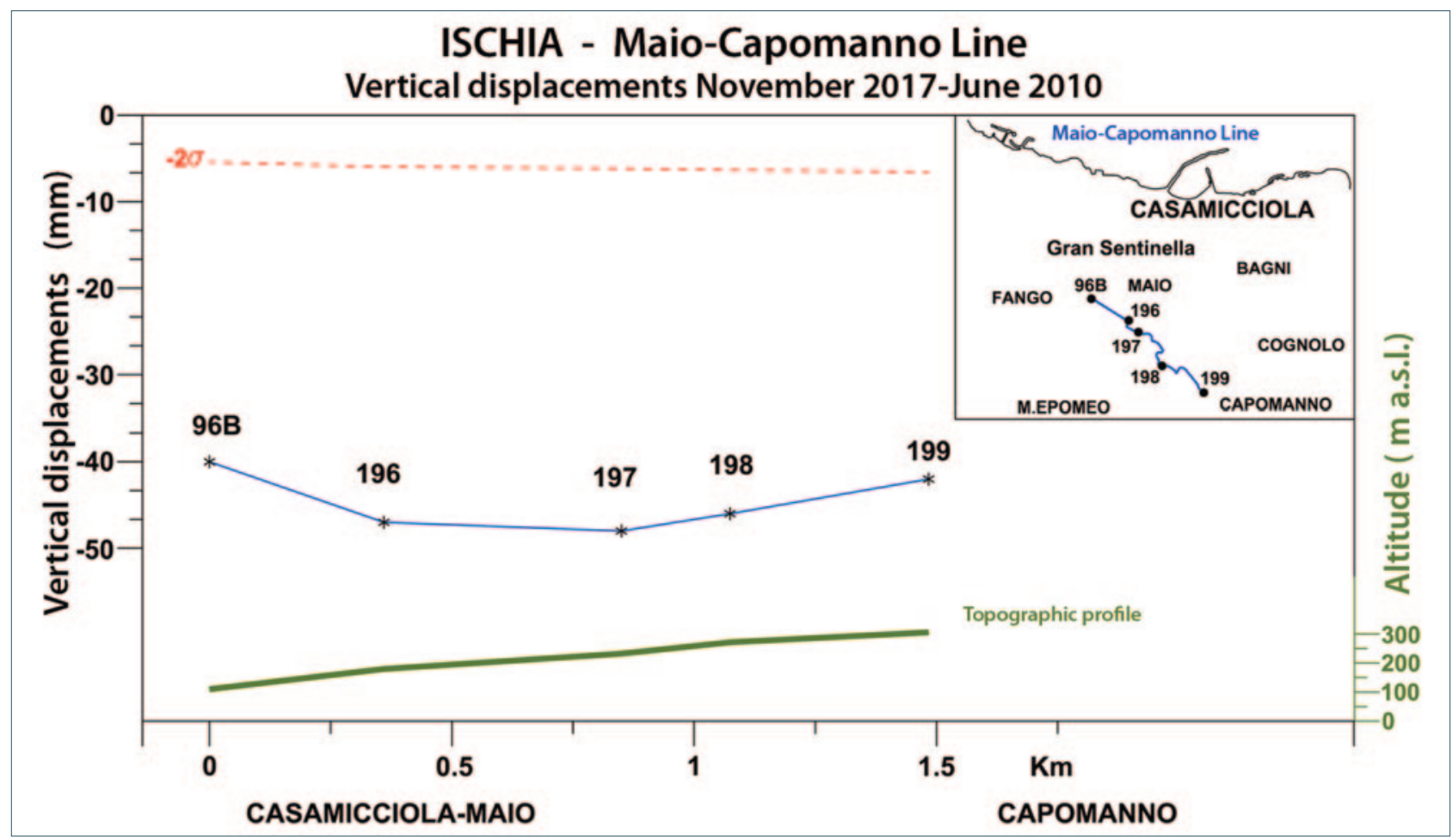

FIGURE 9. "Maio-Capomanno Line”. Differences between the heights measured in 2017 and those of 2010. Blue line with asterisks: vertical displacements; red dotted line: confidence limits 95\%; green line: topographic profile; on the abscissae: the minimum progressive distances between benchmarks; small box: schematic map of the line location.

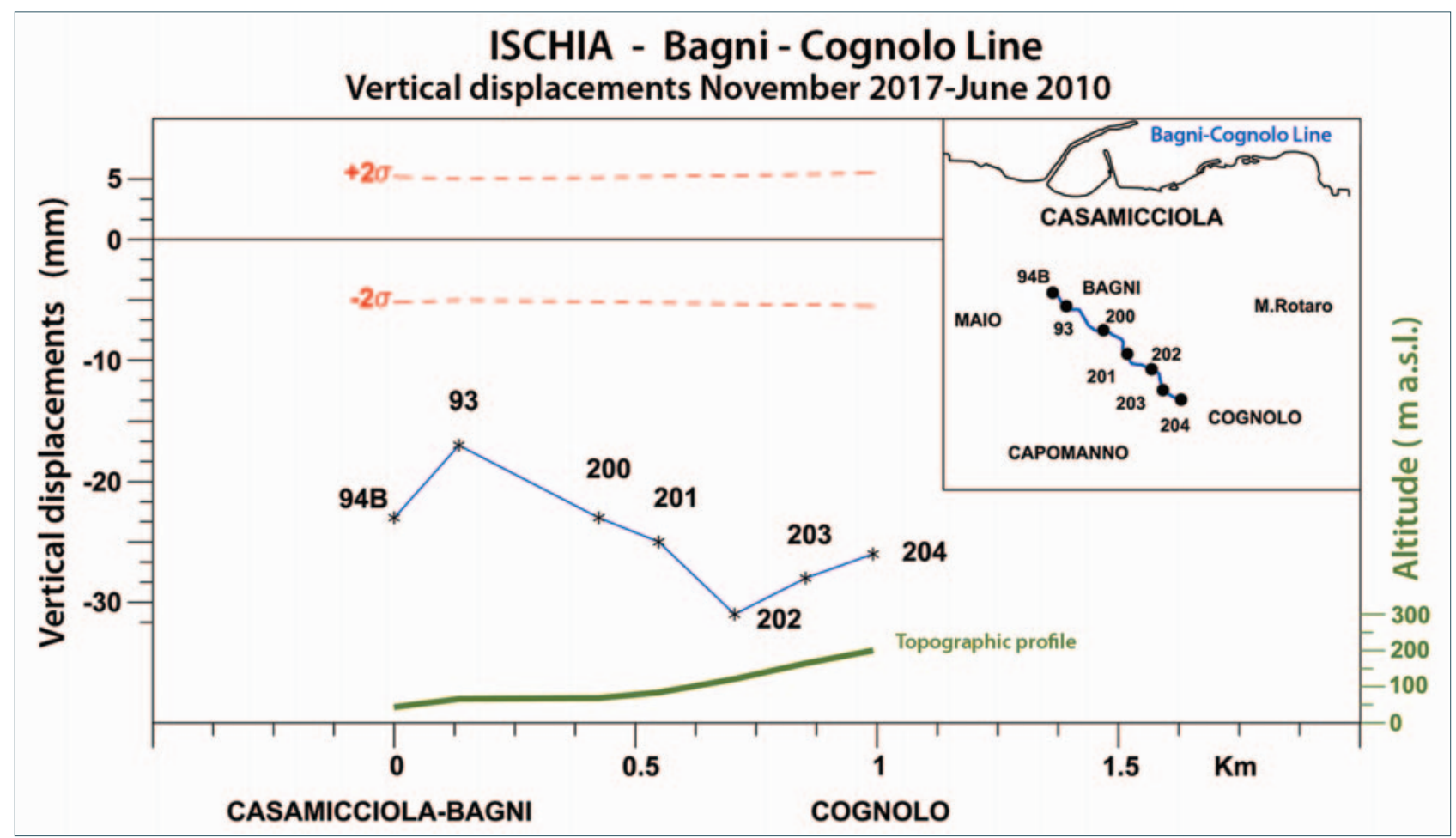

FIGURE 10. "Bagni-Cognolo Line”. Differences between the heights measured in 2017 and those of 2010. Blue line with asterisks: vertical displacements; red dotted line: confidence limits 95\%; green line: topographic profile; on the abscissae: the minimum progressive distances between benchmarks; small box: schematic map of the line location.

- "Mezzavia Line” (Figure 8). A small subsidence is observed starting from Bm 184 which increases until it reaches significant values at Bm 185 and 186, after which the lowering of the ground becomes evident culminating at $\mathrm{Bm} 100 \mathrm{~A}$ (on the Borbonica Line) and then decreasing to the South towards the 


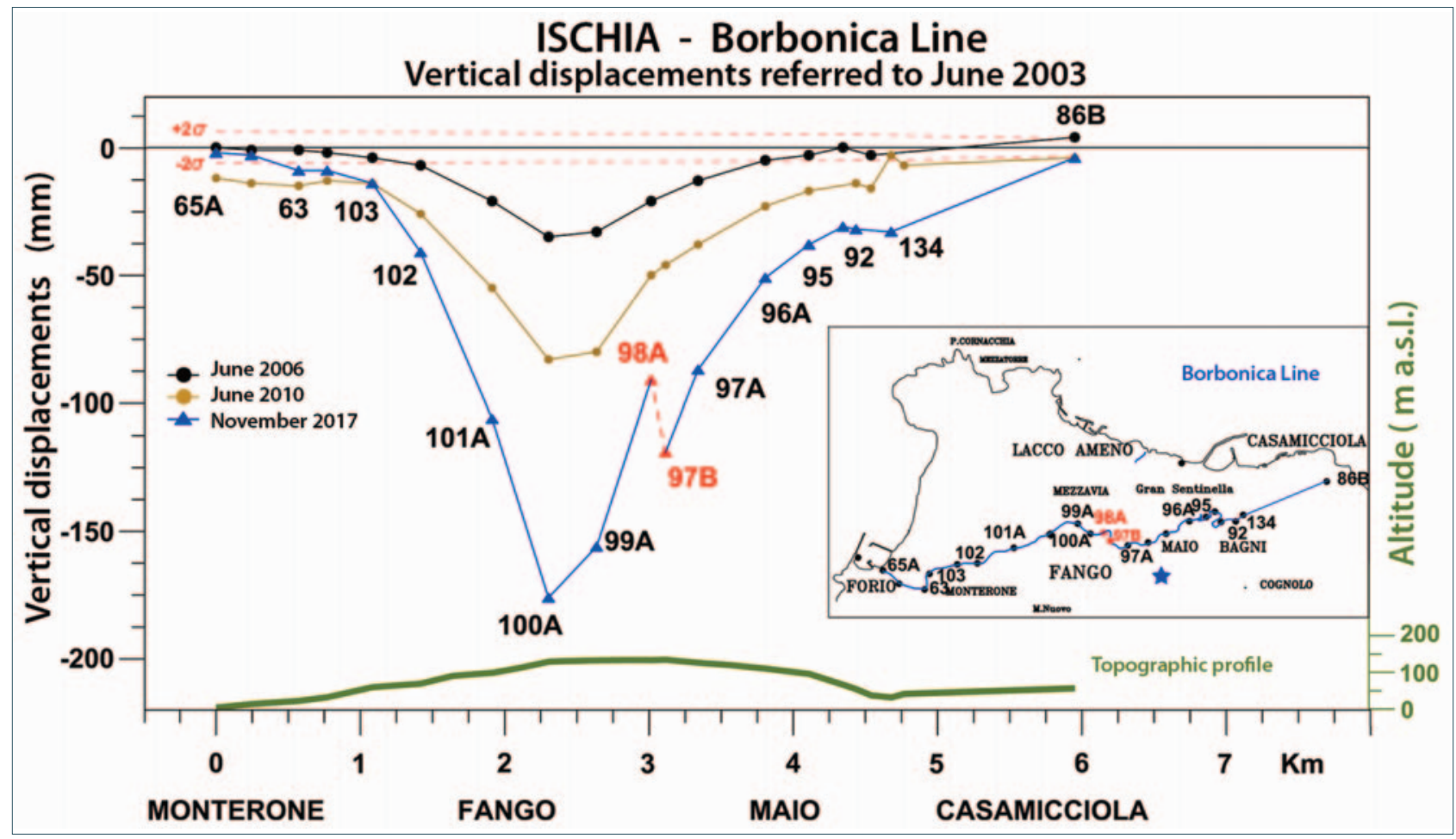

FIGURE 11. "Borbonica Line". Differences between the heights measured in 2017, 2010, 2006 and those of 2003. Vertical displacements: blu line: November 2017-June 2003, brown line: June 2010-June 2003, black line: June 2006-June 2003; red dotted line: confidence limits $95 \%$; green line: topographic profile; on the abscissae: the minimum progressive distances between benchmarks; small box: schematic map of the line location; blue star: 21 August earthquake.

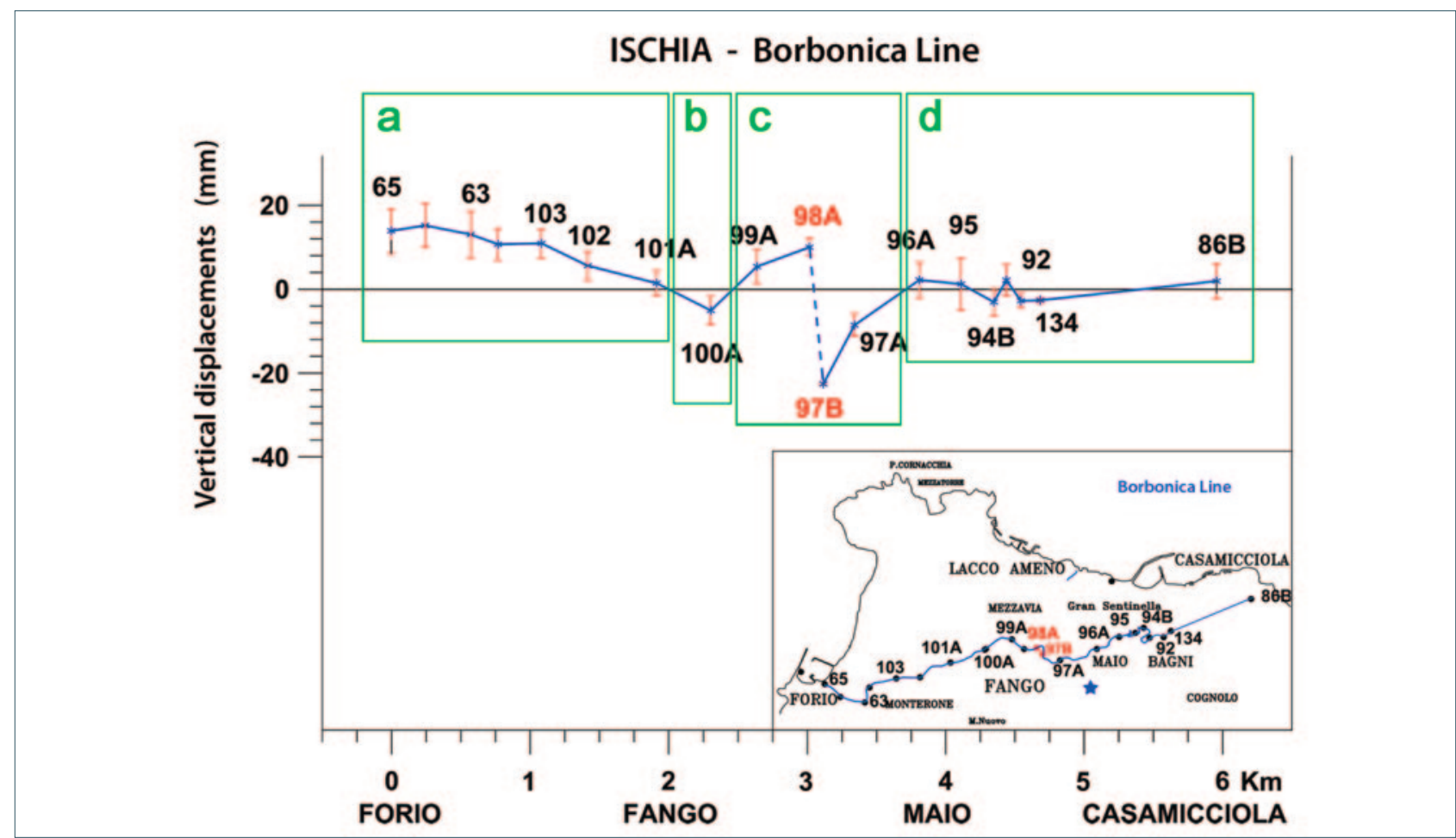

FIGURE 12. Blu line: residual of the vertical displacements for each benchmark along "Borbonica Line" calculated from the average speed difference between the data 1987-2010 and 2010-2017. Vertical red lines: error bars 1:1; green boxes a), b), c), d): delimit the different sectors; black box: location of line; blue star: 21 August earthquake.

Mt. Nuovo on the Bm 222, 223 and 224.

- "Maio-Capomanno Line” (Figure 9). Along this line, defined and measured in 2010, there are negative displacements that denote an almost uniform lowering of the ground of about $45 \mathrm{~mm}$.

• "Bagni-Cognolo Line” (Figure 10). Along this line, 
also defined and measured in 2010, we observe a less uniform but equally significant subsidence between the Bm 93 and 202 with an average value of about $25 \mathrm{~mm}$.

The ground deformation measured during the survey in November 2017 is on the whole comparable with that obtained from the measurements carried out during the past years, with the exception of 3 anomalies detected around the epicentral area of the August 2017 event (Figure 11).

-The first concerns the central-eastern area of the "Borbonica Line" (Bm 92 - Bm 97B) along which there is an increase in the lowering of the ground compared to previous years (measurements of 2010 and 2006 related to those of 2003).

-The second one shows a considerable subsidence between the Bm 97B and 98A, also belonging to the "Borbonica Line".

-The third and last anomaly, even if minor, is observed to the West of the epicentral area where, exactly between the Bm 103 and Bm 65A: this uplift reaches a maximum value of about $10 \mathrm{~mm}$, occurred between 2010 and 2017.

In order to obtain an estimate of the ground deformation possibly related to the Casamicciola earthquake, a "detrending" was applied to the variations in altitude measured in November 2017 along the "Borbonica Line", filtering the "secular" trend, the continuous subsidence found on it since 1987, whose maximum value has always been recorded at $\mathrm{Bm} 100 \mathrm{~A}$ (Mezzavia-Fango).

Then, assuming that the rate of the secular deformation is the same before and after the Casamicciola earthquake, we adjust for this effect by cumulating the long-term deformation over the period 2010-2017 at each benchmark (Figure 12).

On the residual line of vertical displacements we distinguish four sectors with different style of deformation (delimited by the green rectangles in Figure 12), with the main anomaly confined within the epicentral area. Starting from West and moving eastward we observe:

- in the box a (between Bm 65A and Bm 101A) positive residuals indicating a slight uplift (about 10$20 \mathrm{~mm}$ ) affecting the WNW sector of the Ischia island;

- in the box b (Bm 100A) a subsidence (up to $6 \mathrm{~mm}$ ) slightly greater than the long-term value;

- in the box c (between the Bm 99A and the Bm

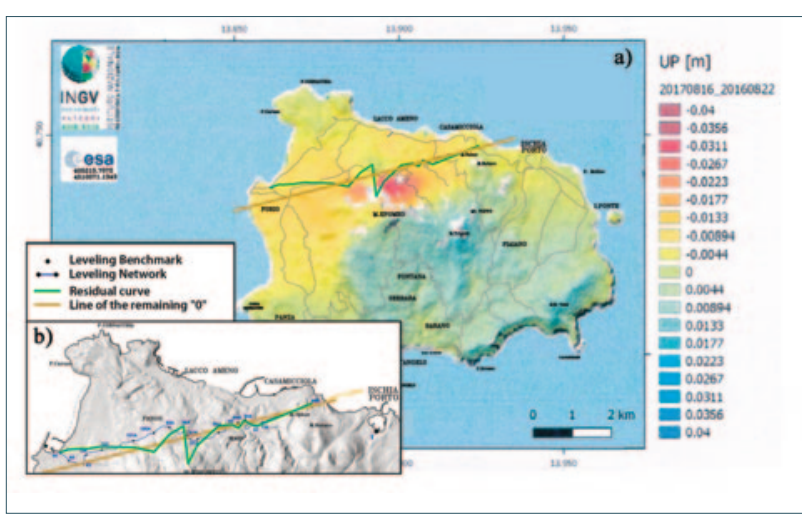

FIGURE 13. a) The SAR image show the vertical coseismic deformation (red area) [from Gruppo di Lavoro INGV sul terremoto dell'isola di Ischia, 2017, modified]. b) Sketch of Ischia map indicating the "Borbonica Line". In a) and b) the residual of the vertical displacements for each benchmark along "Borbonica Line" (in green) and the relative line " 0 " residual (in brown) are overlapped.

97A) the coseismic anomaly is evidently characterized by a ground uplift between 99A and 98A and a marked subsidence between the Bm 98A and Bm 97B;

- in the box d (between the Bm 96A and the 86B) there are no significant changes.

The uncertainties (error bars) have been defined, for each benchmark, by the standard deviation of ground displacement rate evaluated from 1987 to 2010.

\section{DISCUSSION}

The comparison between the altimetric data obtained in November 2017 and those recorded in previous years shows a marked subsidence of the surface of about 36 $\mathrm{mm}$ between the Bm 98A and Bm 97B, both located about $700 \mathrm{~m}$ west of Piazza Maio (Casamicciola) (Figures 7, 11 and Figure 12 box c). Such anomaly is probably attributed to a coseismic deformation offset caused by the August 2017 earthquake.

Furthermore, the residual lowering of about $6 \mathrm{~mm}$, calculated at the Bm 100A in Fango (Lacco Ameno) (Figure 12 box b), could indicate acceleration of the subsidence pattern in the last seven years (2010-2017) that includes the effects of the 21 August earthquake.

The area characterized by the identified anomalies (Figure 12 box $\mathrm{b}$ and $\mathrm{c}$ ) coincides with the greatest macroseismic damages [Azzaro et al., 2017] and with the coseismic surface fractures system along E-W direction 


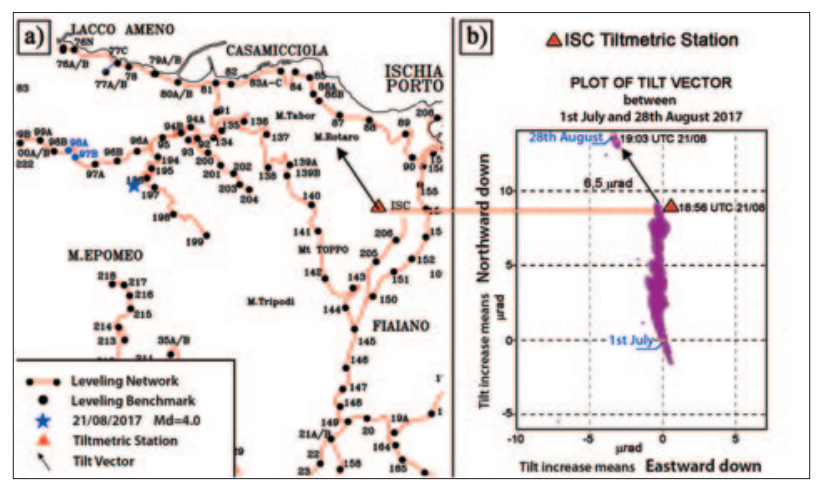

FIGURE 14. Sketch of the leveling network and position of the ISC tiltmetric station (red triangle); the black arrow indicates the orientation of the coseismic tilt. b) Plot of the tilt vector (two clouds, purple color) of points recorded at the ISC station between 1st July and 28th August 2017. The spatial concentrations of points are separated at the on set of the earthquake and this spatial offset is interpreted as a permanent coseismic deformation; the black arrow indicates the permanent coseismic offset $(6.5 \mu \mathrm{rad})$ recorded between 18:56 and 19:03 UTC of 21 August [Ricco et al., 2017].

(between Fango and Piazza Maio), detected by the Emergeo working group [EMERGEO Working Group, Nappi et al., 2017; Nappi et al., 2018].

Inside the same area, also the images obtained from the SAR technique have highlighted two subsiding sectors, one is wider and is related to the epicentral area, the other one is of smaller extension [Gruppo di Lavoro INGV sul terremoto dell'isola di Ischia, 2017; De Novellis et al., 2018].

The overlapping of the residuals line calculated on the vertical displacements to the SAR image (Figure 13a), shows the perfect correspondence both of the subsidence measured between the $\mathrm{Bm}$ 98A and $\mathrm{Bm}$ 97B (area of more extensive and intense red color) and that detected at Bm 100A (smaller area of pink color) (Figure 13a, b).

The effects due to the strong subsidence that mainly interested the central-eastern area of the "Borbonica Line", have been detected also from the tiltmetric station named ISC. This sensor is located about $3 \mathrm{~km}$ in the ESE direction respect to the epicentral area and is installed in a well 25 meters deep (Figure 14a) [Ricco et al., 2017]. The ISC station, together with others two tiltmetric stations (BRN and FOR), belongs to the Ischia Monitoring Tiltmetric Network that is operating on the island from the end of April 2015 [Aquino et al., 2016].

The sensor recorded, between 18:56 and 19:03 UTC of August 21, a coseismic tilt of 6.3 rradians towards NW (Figure 14b); this tilting direction has interrupted the historical trend to NNW that has characterized the site-station since its installation, but it was re-aligned with it immediately after the earthquake [Ricco et al., 2017].

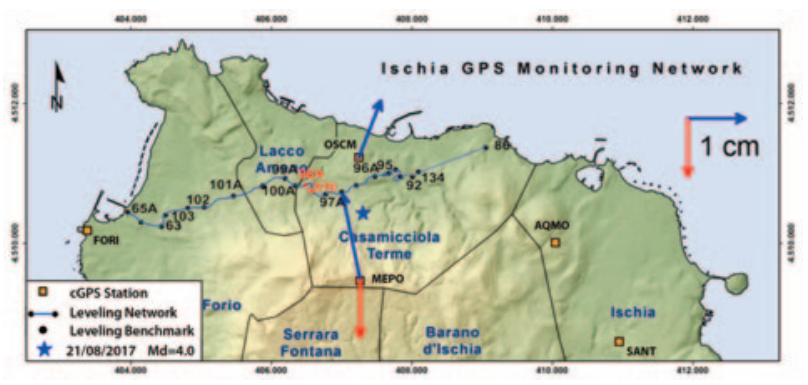

FIGURE 15. Sketch of the cGPS network of Ischia Island on which the "Borbonica Line" is overlapped. The vertical and horizontal coseismic displacements are indicated by the red and blue arrows respectively, recorded at the OSCM and MEPO stations following the earthquake of 21 August 2017 ( $\mathrm{Md}=4.0$ ) [INGV/Osservatorio Vesuviano, Settembre 2017, modified].

Also some stations of the cGPS monitoring network of Ischia (Figure 15) have recorded the coseismic deformation, evaluated through the difference among the averages of their positions 15 days before and 5 days after the event.

The cGPS station named MEPO, operating on Mt. Epomeo, has shown a maximum horizontal displacement of about $1.5 \mathrm{~cm}$ in the NNW direction and a vertical coseismic shift with a lowering of about $1 \mathrm{~cm}$, while the station named OSCM located in Casamicciola has detected a horizontal displacement of about $1 \mathrm{~cm}$ in the NNE direction (Figure 15) [INGV/Osservatorio Vesuviano, Settembre 2017].

\section{CONCLUSIONS}

The results obtained from the high precision leveling survey carried out in the northwestern area of the island identify a localized and pronounced anomaly of ground deformation in the epicentral area of the August 2017 earthquake. Also the tiltmetric station ISC has recorded, between 18:56 and 19:03 UTC of August 21 a coseismic tilt of $6.3 \mu$ radians towards NW (Figure 14) [Ricco et al., 2017], in good agreement with the subsidence observed in the epicentral area.

The comparison between the altimetric data obtained in November 2017 and those recorded in previous years shows a subsidence of about $36 \mathrm{~mm}$ between the Bm 98A and Bm 97B, along the "Borbonica Line" (Figure 12). The area in which we observe this maximum value of subsidence spatially correlates with the deformation detected by the InSAR data analysis (Figure 13) [Gruppo di Lavoro INGV sul terremoto del- 
l'isola di Ischia, 2017; De Novellis et al., 2018].

Moreover this area coincides with the greatest macroseismic damages [Azzaro et al., 2017] and with the coseismic surface fractures system E-W oriented identified by the Emergeo working group [EMERGEO Working Group, Nappi et al., 2017; Nappi et al., 2018]. The leveling measurements performed, together with the fracturing system extensively observed in the hanging wall of this fault immediately after the earthquake, have shown that the seismic event caused the lowering of the block to the north of Mt. Epomeo. The observed ground deformation anomaly results properly correlated with the fault motion at surface, as it has been hypothesized in the geological source model by Nappi et al., [2018] and InSAR source model by Montuori et al., [2018] and Albano et al., [2018] . These Authors consider the reactivation of the E-W fault systems, northward dipping, that borders the Mt Epomeo's northern flank, as the tectonic structure responsible for the August 21, 2017 Casamicciola earthquake. Nevertheless Albano et al., [2018] suggest that the observed ground displacements can also be interpreted as the combination of tectonic and non-tectonic phenomena, i.e., as due to the fault slip and the earthquake-induced landslides, respectively.

In conclusion, the leveling survey performed on November 2017 on a sector of the altimetric network of the island of Ischia has provided a quantitative measurement, with high degree of accuracy and precision, of the vertical displacement in the epicentral area, confirmed also by other geodetic methodologies as well as by the ground effects geological surveys. It is necessary that further leveling measurements, extended to the whole altimetric network of the island, will be carried out in future, in order to infer and understand the recent dynamics of the whole island.

\section{REFERENCES}

Acocella, V. and R. Funiciello (1999). The interaction between regional and local tectonics during resurgent doming: The case of the island of Ischia, Italy, Journal of Volcanology and Geothermal Research, v. 88, pp. 109-123, doi: 10.1016/S0377-0273(98)00109-7.

Albano, M., M. Saroli, A. Montuori, C. Bignami, C. Tolomei, M. Polcari, G. Pezzo, M. Moro, S. Atzori, S. Stramondo and S. Salvi (2018). The Relationship between InSAR Coseismic Deformation and Earth-
quake-Induced Landslides Associated with the 2017 Mw 3.9 Ischia (Italy) Earthquake, Geosciences 2018, 8, 0303; doi: 10.3390/geosciences8080303.

Alessio, G., E. Esposito, L. Ferranti, G. Mastrolorenzo, and S. Porfido (1996). Correlazione tra sismicità ed elementi strutturali nell'isola d'Ischia, Il Quaternario, 9 (1) 303-308.

Amoruso, A., L. Crescentini, R. Scarpa (1988). Inversion of source parameters from near- and far-field observations: An application to the 1915 Fucino earthquake, central Apennines, Italy, Journal of Geophysical Research Vol. 103, No. B12, Pages 29,989-29,999, December 10, 1998 https://doi.org/10.1029/98JB02849

Aquino, I., C. Ricco, C. Del Gaudio, V. Augusti, G. Scarpato (2016). Potenziamento delle reti tiltmetriche nell'area vulcanica campana: Rapporto sull'attività svolta nell'ambito del progetto Vulcamed, Rapporti Tecnici INGV, N. 348, ISSN 2039-7941.

Arca, S., and G.P. Beretta, (1985). Prima sintesi geodetico - geologica sui movimenti verticali del suolo nell'Italia Settentrionale (1897-1957), Boll. Geod. Sci. Affini 2, 125-156.

Arnadottir, T., P. Segall, M Matthews (1992). Resolving the discrepancy between geodetic and seismic fault models for the 1989 Loma Prieta, California, Bulletin of the Seismological Society of America, Vol. 82, No. 5, pp. 2248-2255, October 1992

Azzaro, R., S. Del Mese, G. Martini, S.Paolini, A. Screpanti, V. Verrubbi, A. Tertulliani (2017). QUEST, Rilievo macrosismico per il terremoto dell'isola di Ischia del 21 agosto 2017, Rapporto interno, doi: 10.5281/zenodo.849091.

Bartole, R., (1984). Tectonic structures of the LatianCampanian shelf (Tyrrhenian Sea), Bollettino di Oceanografia Teorica e Applicata, v. 2, pp. 197 230.

Bruno, P.P.G., G. de Alteriis, G. Florio (2002). The western undersea section of the Ischia volcanic complex (Italy, Tyrrhenian Sea) inferred by marine geophysical data, Geophysical Research Letters doi: 10.1029/2001GL013904.

Cheloni, D., N. D’Agostino, E. D’Anastaso, G. Selvaggi (2012). Reassessment of the source of the 1976 Friuli, NE Italy, earthquake sequence from the joint inversion of high-precision levelling and triangulation data, Geophysical Journal International, Volume 190, Issue 2, 1 August 2012, Pages 1279-1294, https://doi.org/10.1111/j.1365-246X.2012.05561.X 
Chiesa, S., S. Poli and L. Vezzoli, (1986). Studio dell'ultima eruzione storica dell'isola di Ischia, Bollettino del Gruppo Nazionale di Vulcanologia, pp. 153-166.

Chiodini, G., R. Avino, T. Brombach, S. Caliro, C. Cardellini, S. de Vita, F. Frondino, D. Granieri, E. Marotta, G. Ventura, (2004). Fumarolic and diffuse soil degassing west of Mount Epomeo, Ischia, Italy, Journal of Volcanology and Geothermal Research, v. 133, pp. 291-309.

Civetta, L., G. Gallo and G. Orsi (1991). Sr- and Nd- isotope and trace-element constraints on the chemical evolution of the magmatic systemof Ischia (Italy) in the last $55 \mathrm{ka}$, Journal of Volcanology and Geothermal Research, v. 46, pp. 213-230, doi: 10.1016/0377-0273(91)90084-D.

Gruppo di Lavoro CPTI (2004). Catalogo Parametrico dei Terremoti Italiani, versione 2004 (CPTI04), INGV, Bologna. doi:10.6092/INGV.IT-CPTI04.

Cubellis, E. and G. Luongo (1998). Il terremoto del 28 luglio 1883 a Casamicciola nell'isola d'Ischia. Il contesto fisico, Servizio Sismico Nazionale, Istituto Poligrafico e Zecca dello Stato. Vol. 1, pp. 49-123.

D’Anastasio, E, P. De Martini, G. Selvaggi, D. Pantosti, A. Marchioni, R. Maseroli (2006). Short-term vertical velocity field in the Apennines (Italy) revealed by geodetic levelling data, Tectonophysics, ISSN: 00401951, doi: 10.1016/j.tecto.2006.02.0.

D’Argenio, B., T. Pescatore and P. Scandone (1973). Schema geologico dell'Appennino meridionale (Campania e Lucania), Atti del Convegno Moderne vedute sulla Geologia dell'Appennino: Roma, Accademia Nazionale dei Lincei, p. 183.

De Novellis, V., S. Carlino, R. Castaldo, A. Tramelli, C. De Luca, N.A. Pino, S. Pepe, V. Convertito, I. Zinno, P. De Martino, M. Bonano, F. Giudicepietro, F. Casu, G. Macedonio, M. Manunta, C. Cardaci, M. Manzo, D. Di Bucci, G. Solaro, G. Zeni, R. Lanari, F. Bianco, and P. Tizzani (2018). The 21st August 2017 Ischia (Italy) earthquake source model inferred from seismological, GPS and DInSAR measurements, Geophys. Res. Lett., 45, 1-10. Doi: 10.1002/2017GL076336.

de Vita, S., F. Sansivero, G. Orsi, and E. Marotta (2006). Cyclical slope instability and volcanism related to volcano-tectonism in resurgent calderas: The Ischia island (Italy) case study, Engineering Geology, v. 86, p. 148- 165, doi: 10.1016/j.enggeo.2006.02.013.

de Vita, S., F. Sansivero, G. Orsi, E. Marotta, M. Piochi (2010). Volcanological and structural evolution of the Ischia resurgent caldera (Italy) over the past 10 k.y., The Geological Society of America Special Paper 464: 193-241.

Del Gaudio, C., F. Obrizzo, C. Ricco (1987). Ristrutturazione della rete altimetrica e livellazione di precisione ad Ischia, Rapporto interno Osservatorio Vesuviano Giugno 1987.

Del Gaudio, C., I. Aquino, C. Ricco, V. Sepe, C. Serio, (2011). Monitoraggio geodetico dell'isola d'Ischia: risultati della livellazione geometrica di precisione eseguita a Giugno 2010, Quaderni di Geofisica, N. 87, ISSN 1590-2595.

Del Prete, S., and R. Mele, (2006). Il contributo delle informazioni storiche per la valutazione della propensione al dissesto nell'Isola d'Ischia (Campania), Rend. Soc. Geol. It. 2, 29-47.

Dzurisin, D. (2003). A comprehensive approach to monitoring volcano deformation as a window on the eruption cycle, Rev. Geophys., 41(1), 1001, doi: 10.1029/2001RG000107

EMERGE0 Working Group: Nappi, R., G. Alessio, P. Belviso, G. Gaudiosi, E. Marotta, R. Nave, R.Peluso, V. Siniscalchi, R. Civico, L. Pizzimenti, and S. Porfido (2017). The August 21, 2017 Isola di Ischia (Casamicciola) earthquake: Coseismic effects, https://doi: 10.5281/zenodo.1003188 DPC Report. Esposito, E., S. Porfido, and E. Vittori (2006). Earthquake hazard in the Island of Ischia (Campania, Italy), Abstract EGU 2006, https://doi: 10.13140/RG.2.2.33895.34722.

Finetti, I. and C. Morelli (1974). Esplorazione sismica a riflessione dei Golfı di Napoli e Pozzuoli, Bollettino di Geofisica Teorica e Applicata, v. 16, pp. 175-222.

Gillot, P.Y., S. Chiesa, G. Pasquarè and L. Vezzoli (1982). $<33,000 \mathrm{yr} \mathrm{K}$-Ar dating of the volcano-tectonic horst of the Isle of Ischia, Gulf of Naples, Nature, v. 299, pp. 242-245, doi: 10.1038/299242a0.

Guadagno, F.M., R. Mele, (1995). La fragile isola d'Ischia, Geol. Appl. Idrogeol. 30:177-187.

Gruppo di Lavoro INGV sul terremoto dell'isola di Ischia (2017). Rapporto di sintesi preliminare sul Terremoto dell'isola d'Ischia (Casamicciola) M4.0 del 21 agosto 2017 (6 settembre 2017), doi: 10.5281/zenodo.886045.

INGV-Osservatorio Vesuviano (2000). Rendiconto sull'attività di sorveglianza $2^{\circ}$ semestre 1999, pp.66-75. INGV-Osservatorio Vesuviano (2001). Rendiconto sull'attività di sorveglianza $2^{\circ}$ semestre 2000 , p.70

INGV-Osservatorio Vesuviano (2002). Rendiconto sull'attività di sorveglianza $1^{\circ}$ semestre 2001, pp.66-69. 
INGV-Osservatorio Vesuviano (2002). Rendiconto sull'attività di sorveglianza $2^{\circ}$ semestre 2001, pp.45-65

INGV-Osservatorio Vesuviano (2004). Attività di sorveglianza dell'Osservatorio Vesuviano, Rendiconto anno 2002 pp.83-85.

INGV (2005). Rendiconto dell'attività svolta nel 2004 e nel primo semestre 2005, Monografie istituzionali INGV Vol. VII - appendice 2005, pp.118-126 http://venus.ov.ingv.it/ingv/Rapporto_INGV-DPC2004-Isem2005.pdf

Iacono, A., (1996). La “Guerra d'Ischia”, In De Bello Neapolitano di G. Pontano, Quaderni dell'Accademia Pontaniana, v. 19, pp 1-90.

Inghilleri, G. (1974). Topografia Generale, UTET, Torino. INGV/Osservatorio Vesuviano, (2017): Bollettino di Sorveglianza Osservatorio Vesuviano. Ischia, Settembre 2017.

http://www.ov.ingv.it/ov/bollettini-mensili-campania/Bollettino_Mensile_Ischia_2017_09.pdf

Ippolito, F., F. Ortolani and M. Russo, (1973). Struttura marginale tirrenica dell'Appennino Campano: Reinterpretazione di dati di antiche ricerche di idrocarburi, Memorie della Società Geologica Italiana, v. 12, pp. 227-250.

Loperfido, A. (1914). Livellazione geometrica di precisione. Isola d'Ischia e Vesuvio.Tipografia Barbera, Firenze.

Luongo, G., C. Del Gaudio, F. Obrizzo, C. Ricco (1990). Precision levelling. In: Mt. Etna: the 1989 eruption, C.N.R. Gruppo Nazionale per la Vulcanologia Italy. Edited by F. Barberi, A. Bertagnini, P. Landi. (Giardini), pp. 52-55

Luongo, G., S. Carlino, E. Cubellis, I. Delizia, R. Iannuzzi, and F.Obrizzo (2006). Il terremoto di Casamicciola del 1883: una ricostruzione mancata, Alfa Tipografia, Napoli, 1-64.

Mele, R. and S. Del Prete (1998). Fenomeni di instabilità dei versanti in Tufo Verde del Monte Epomeo (Isola d'Ischia-Campania), Boll Soc Geol Ital 117:93-112.

Montuori, A., M. Albano, M. Polcari, S. Atzori, C. Bignami, C. Tolomei, G. Pezzo, M. Moro, M. Saroli, S. Stramondo, S. Salvi (2018). Using multi-frequency insar data to constrain ground deformation of ischia earthquake, 2017 IEEE International Geoscience and Remote Sensing Symposium (IGARSS), 22-27 July.

Murase, M., F. Kimata, Y. Yamanaka, S. Horikawa, K. Matsuhiro, T. Matsushima, H. Mori, T. Ohkura, S. Yoshikawa, R. Miyajima, H. Inoue, T. Mishima, T. Sonoda, K. Uchida, K. Yamamoto and H. Nakamichi (2016). Preparatory process preceding the 2014 eruption of Mount Ontake volcano, Japan: insights from precise leveling measurements, Earth, Planets and Space 68:9 doi: 10.1186/s40623-016-0386-4

Nappi, R., G. Alessio, and E. Bellucci Sessa (2010). A case study comparing landscape metrics to geologic and seismic data from the Ischia Island (Southern Italy), Applied Geomatics, 2, 73-82 doi: 10.1007/s12518010- $0023 \mathrm{z}$.

Nappi, R., G. Alessio, G. Gaudiosi, R. Nave, R. Marotta E, V. Siniscalchi, R. Civico, L. Pizzimenti, R. Peluso, P. Belviso, S. Porfido (2018). The August 21, 2017, Mw 4.0 Casamicciola earthquake: first evidence of surface extensional faulting at the Ischia volcanic island. Seismological Research Letter, 89 (4):13231334 doi: 10.1785/0220180063

Obrizzo, F., F. Pingue, C. Troise, G. De Natale (2001). Coseismic displacements and creeping along the Pernicana fault (Etna, Italy) in the last 17 years: a detailed study of a tectonic structure on a volcano, Journal of Volcanology and Geothermal Research, v. 109, pp. 109-131, ELSEVIER.

Orsi, G., G. Gallo and A. Zanchi (1991). Simple-shearing block resurgence in caldera depression. A model from Pantelleria and Ischia, Journal of Volcanology and Geothermal Research, v. 47, pp. 1-11, doi: 10.1016/0377- 0273(91)90097-J.

Orsi, G., S. de Vita and M. Piochi, (1994). Ischia: A volcanic island. In Carannante, G., and Tonielli, R., eds., International Association of Sedimentologists 15th Regional Meeting, April 1994, Ischia, Italy, Field trip Guide book: Napoli, De Frede, pp. 107-123.

Orsi, G., L. Civetta, C. Del Gaudio, S. de Vita, M.A. Di Vito, R. Isaia, S.M. Petrazzuoli, G.P. Ricciardi and C. Ricco, (1999). Short-term ground deformations and seismicity in the resurgent Campi Flegrei caldera (Italy): An example of active block-resurgence in a densely populated area, Journal of Volcanology and Geothermal Research, 91, 415-451.

Osservatorio Vesuviano (1979). Progetto finalizzato "Geodinamica”. Rapporto U.0. 3.1.1.: Deformazioni del suolo Campi Flegrei - Ischia - Vulcano. A cura di Corrado, G., M. Grimaldi, A. Lo Bascio, G. Luongo, Monografia.

Piochi, M., L. Civetta and G. Orsi (1999). Mingling in the magmatic system of Ischia (Italy) in the past $5 \mathrm{ka}$, Mineralogy and Petrology, v. 66, pp. 227-258, doi: 10.1007/BF01164495.

Piochi, M., P.P. Bruno and G. De Astis (2005). Relative roles of rifting tectonics and magma ascent pro- 
cesses: Inferences from geophysical, structural, volcanological and geochemical data for the Neapolitan volcanic region (southern Italy), G3, v. 6, no.7, Q07007, doi: 10.1029/2004GC000885.

Ricco, C., V. Augusti, G. Scarpato e I. Aquino (2017).

https://ingvterremoti.wordpress.com/2017/12/12/la-deformazione-del-suolo-ad-ischia-rilevata-dalla-retetiltmetrica/. Blog INGVterremoti.

Sacchi, M., G. Alessio, I. Aquino, E. Esposito, F. Molisso, R. Nappi, S. Porfido, C. Violante (2009). Risultati preliminari della campagna oceanografica CAFE_07-Leg 3 nei Golfı di Napoli e Pozzuoli, Mar Tirreno Orientale, Quaderni di Geofisica, N. 64, ISSN 1590-2595.

Sepe, V., S. Atzori, and G. Ventura (2007).Subsidence due to crack closure and depressurization of hydrothermal systems: a case study from Mt Epomeo (Ischia Island, Italy), Terra Nova, vol.19, p.127-132, doi:10.1111/j.1365-3121.2006.00727.x

Sepe, V., G. Ventura, G. Vilardo (2009). Integrated methodologies for 3D deformation analysis at Ischia Island (Italy): state of the art, prospectives and modelling, Proceeding to ISDE 2009, Pechino 09-12 settembre 2009. Extended abstract and Oral presentation.

Tibaldi, A., and L. Vezzoli (1998). The space problem of caldera resur-gence: An example from Ischia Island, Italy, Geol. Rundschau, 87, 53-66.

Tibaldi, A. and L. Vezzoli (2000). Late Quaternary monoclinal folding induced by caldera resurgence at Ischia, Italy, In Cosgrove, J.W., and Ameen, M.S., eds., Forced Folds and Fractures: Geological Society of London Special Publication 169, pp. 103-113.

Tibaldi, A. and L. Vezzoli (2004). A new type of volcano fl ank failure: The resurgent caldera sector collapse, Ischia, Italy, Geophysical Research Letters, v. 31, doi: 10.1029/2004GL020419.

Vezzoli, L. (1988). Island of Ischia, Consiglio Nazionale delle Ricerche, Quaderni de "La Ricerca Scientifica," v. 114, no. 10, p. 122.

Yeats, R.S., K. Sieh, C.R. Allen (1997). The Geology of Earthquakes, Oxford University Press.

"CORRESPONDING AUTHOR: Ida AQUINO,

Istituto Nazionale di Geofisica e Vulcanologia, sezione di Napoli, Osservatorio Vesuviano Napoli, Italy email: ida.aquino@ingv.it 
